http://dx.doi.org/10.12775/szhf.2021.013

\author{
Sarah Hutton \\ Department of Philosophy, University of York, United Kingdom \\ E-MAIL: SARAH.HUTTON@YORK.AC.UK \\ ORCID: 0000-0002-7754-2858
}

\title{
Damaris Masham, Ralph Cudworth and John Locke: Some Philosophical Continuities
}

\author{
I should be glad to more Clearely and fully to understand \\ the Difference betweene you and some friends \\ of Mine,... Being not sure the Difference \\ betweene You, is Really so great as it Seemes. \\ (Lady Masham to John Locke, 7 April 1688) ${ }^{1}$
}

\footnotetext{
Abstract: In this paper, I focus on Damaris Masham, to re-consider the relationship of her philosophy to the two philosophers with whom she was most closely associated: John Locke, and her father, the Cambridge Platonist, Ralph Cudworth. After considering some of the problems of interpretation which have arisen in scholarly

1 John Locke, The Correspondence of John Locke, ed. E. S. de Beer, vol. 3 (Oxford: Clarendon Press, 1976-1989), 433. The quotation from Henry More which follows indicates that her "friends" are the Cambridge Platonists. In this paper I return to a theme which I have discussed on a number of occasions - first with the title "Like Father, Like Daughter? Damaris Masham, Ralph Cudworth and John Locke", at the APA conference in 1996.
} 
debates, I focus her Occasional Thoughts to highlight continuities with both Locke and Cudworth in her epistemology, moral philosophy and metaphysics. I argue these show that Damaris Masham's philosophy does not fit the received categories of empiricist or rationalist of the dominant narrative. Her position requires us to reconsider not just the relationship of her philosophy to that of Cudworth and Locke, but also of the relationship of Cudworth and Locke. Ultimately, therefore, reintegrating women into the history of philosophy challenges us to rethink standard narratives of the history of philosophy.

Keywords: Damaris Masham, Ralph Cudworth, John Locke, Platonism

\section{Introduction}

Recent interest in women's contribution to philosophy raises many questions about their relationship to their philosophical contemporaries and how to integrate them in the history of philosophy. One answer is to treat philosophy as a conversation between philosophers, and thereby to show they contributed to the philosophical debates of their time. ${ }^{2}$ In this paper, I argue that it is important to include non-canonical philosophers in those conversations. To ignore them distorts our understanding of women's contribution. I focus on Damaris Masham to re-consider the relationship of her philosophy to the two philosophers with whom she was most closely associated: John Locke, and her father, the Cambridge Platonist, Ralph Cudworth. I first consider some of the problems of interpretation which have arisen in scholarly debates where the entrenched view of the history of seventeenth-century philosophy as a narrative empiricism versus rationalism retains its hold. I then focus her Occasional Thoughts to highlight continuities with both Locke and Cudworth in her epistemology, moral philosophy and metaphysics - all areas

2 Jacqueline Broad, Women Philosophers of Seventeenth-Century England: Selected Correspondence (Oxford: Oxford University Press, 2020), 13; Lisa Shapiro, “The Place of Women in Early Modern Philosophy", in Feminist Reflections on the History of Philosophy, ed. Lilli Alanen, Charlotte Witt (Dordrecht: Kluwer, 2004); Sarah Hutton, "Blue-eyed Philosophers Born on Wednesdays': An Essay on Women and History of Philosophy”, The Monist 98, 1 (2015). 
of philosophical debate of her time. I argue these show that Damaris Masham's philosophy does not fit the received categories of empiricist or rationalist of the dominant narrative, and her position requires us to reconsider not just the relationship of her philosophy to Cudworth and Locke, but also of the relationship of Cudworth and Locke. Ultimately, therefore, reintegrating women into the history of philosophy requires us to rethink standard narratives of the history of philosophy.

\section{Damaris Masham among the Philosophers}

Damaris Cudworth, Lady Masham, published only two books: A Discourse Concerning the Love of God and Occasional Thoughts in Reference to the Christian Life, slim octavo volumes which were published anonymously. At one time, the question of where to place Damaris Masham as a philosopher seemed to be settled on quantity alone: small books make only minor contributions to philosophy. The fact that they were misattributed to Locke could be taken as some confirmation of their philosophical content, but it only served to confirm her secondary status. ${ }^{3}$ As a lady admirer of Locke, she was not an original mind but deserving of commendation for recognising Locke's importance. Her good philosophical taste in joining the Locke admiration society gave her a ride on his philosophical coat tails (so to speak). So she did not need to be dismissed completely out of hand.

Since the early days of the recovery of women philosophers, a lot has changed. Where once the only way to get attention for women philosophers was to link her to a famous male philosopher - in Damaris's case, John Locke it is no longer necessary to have to ask whether women philosophers should be accorded attention because of their closeness to a "great" philosopher.

3 Occasional Thoughts was republished as Thoughts on a Christian Life. By John Locke, Esq. In 1747. Richard Gwinnett mistook the anonymous 1705 first printing as by Locke - Jaqueline Broad, "A Woman's Influence? John Locke and Damaris Masham on Moral Accountability". Journal of the History of Ideas (2006), 489-490. 
Damaris Masham is now considered a philosopher in her own right. ${ }^{4} \mathrm{Her}$ philosophical credibility is no longer held to reside wholly in her being designated a "disciple" of Locke. The pendulum is now swinging the other way, and scholars are beginning to ask whether she might have influenced him. ${ }^{5}$

The case of Damaris Masham aptly illustrates the dangers of approaching women philosophers via their male peers. However, recognising women as philosophers in their own right does not mean that we should ignore such engagement. Philosophy, after all, is a dialogic exercise. And the male interlocutors of women philosophers - Descartes for Princess Elisabeth, Locke and Leibniz for Damaris Masham - have helped preserve their visibility for posterity. Even when a woman is treated as a philosopher in her own right, her engagement with her philosophical peers can provide insight into her own philosophy. However, a drawback about this is that we are only likely to see what we recognise, and what is most familiar to most of us are the canonical philosophers. This is especially true in relation to their contribution to philosophical debates as presented in the standard accounts of the history of philosophy. In consequence, it is the canonical perspective that still tends to dominate the interpretation of women's philosophy. But canonical philosophers are not the only philosophers relevant here. In fact, it is often the case that the thinkers with whom many women philosophers engaged were figures who are no longer revered as significant philosophers - e.g. Henry More for Anne Conway and John Norris for Mary Astell. To ignore women's engagement with such figures risks distorting our interpretation of their philosophy and misjudging their contribution to the history of philosophy.

The problem is illustrated by the case of Damaris Masham, who has links to both a mainstream canonical philosopher (John Locke) and a philosopher who is usually considered a "minor" figure (Ralph Cudworth). The relationship of her philosophy to Cudworth and the Platonising tradition which he

4 For recent studies on Masham as a philosopher see my Stanford Encyclopedia article: Sarah Hutton, "Lady Damaris Masham", The Stanford Encyclopedia of Philosophy (Winter 2020 Edition), ed. Edward N. Zalta, https://plato.stanford.edu/archives/win2020/entries/lady-masham.

A question I posed in 1993, see Sarah Hutton, "Damaris Cudworth, Lady Masham: Between Platonism and Enlightenment", British Journal for the History of Philosophy 1, 1 (1993): 29-54. Jaqueline Broad has since argued the case more fully, “A Woman's Influence?". 
represents (aka Cambridge Platonism) have not been completely ignored, ${ }^{6}$ but it is a matter of dispute, largely because of the undeniable Lockean echoes in her philosophy. Reconciling both strands in her philosophical formation is problematic within the standard categories of empiricist and rationalist by which seventeenth-century philosophical history is standardly mapped. The claim that there might be a Platonist element in Damaris Masham's philosophy has been rendered contentious by two particular commentators: first in a 2005 article by James Buickerood who attacked what he called the "regnant" view that she was indebted to Cambridge Platonism, or any other Platonism for that matter. ${ }^{7}$ Taking her lead from James Buickerood, Patricia Springborg has since asserted that, far from being a Platonist, Damaris attacks them:

Masham... rather than being a Platonist, after her father Ralph Cudworth, and despite the Cambridge Platonists she numbers among her friends - without necessarily subscribing to their views... [was] a doctrinal minimalist opposed to the fractiousness induced by rival Christian camps. If so, she would have come close to the positions of Hobbes and Locke, the former of whom believed Cambridge Platonism the best example of "Gratification" of Christianity by unemployed and under employed philosophers... ${ }^{8}$

6 See Hutton, "Damaris Cudworth, Lady Masham"; two papers by Jacqueline Broad: "A Woman's Influence?" and "Adversaries or Allies? Occasional Thoughts on the MashamAstell Exchange", Eighteenth-Century Thought 1 (2003), which cite my paper "Like Father, Like Daughter" (see note 1). For an overview of Cudworth's philosophy, see my entry, "Ralph Cudworth," in The Stanford Encyclopedia of Philosophy, https://plato.stanford.edu/archives/ sum2021/entries/cudworth/.

7 James G. Buickerood, "What is it with Damaris, Lady Masham?", The Historiography of one early-modern woman philosopher", Locke Studies. An Annual Journal of Locke Research 5 (2005): 180-181. This article attacks almost every chapter and article that has been written on Damaris Masham between 1994 and 2005. See the reply by Richard Acworth, "Cursory reflections upon an article called 'What is it with Damaris, Lady Masham?", Locke Studies 5 (2006): 179-197.

8 Patricia Springborg, Mary Astell: Theorist of Freedom from Domination (Cambridge University Press, 2005), 69. For a corrective to Springborg's account of Locke, see Mark Goldie, "Mary Astell and John Locke", in Mary Astell: Reason, Gender, Faith, eds. William Kolbrener, Michal Michelson (Routledge, 2007). 
Accordingly, Patricia Springborg reads Damaris Masham as an anti-Platonist, citing Masham's reference to "the mystical divines" whose "revolt against the passions has led them to dress out in an intire System intelligible only by Sentiment, not to Reason". 'These "mystical divines" are, Springborg claims, an example of Platonist "extravagance", and she interprets Masham's remark as dealing "a cruel blow to the Platonists". Aside from the dubious suggestion that Masham's position might be close to that of Hobbes, a problem with both these opinions is that they are based on a limited, even erroneous, conception of Platonism, especially in its early modern varieties.

\section{Against the Platonists}

Damaris Masham's Platonist credentials seem, on the face of it, improbable - partly for the reason that there is no significant reference to Plato or the Cambridge Platonists, in her published writings, and partly because of the clear echoes of Locke in her those writings. We know from her correspondence that she certainly read the Cambridge Platonists. She discusses John Smith's Select Discourses in her correspondence with Locke and quotes from Henry More in the same correspondence. She knew her father's True Intellectual System well enough to be able to discuss it with Leibniz. ${ }^{10}$ But her familiarity with their work in these letters does not mean that she subscribed to their views.

Another reason for not considering Damaris a Platonist is that her philosophy is grounded in the everyday. Far from being an idealist, she focuses on this life, vindicates sensual pleasure, emphasises practical morality, and conceives of human beings as social beings: "There is nothing more evident", she writes in A Discourse, "than that Mankind is design'd for a Sociable Life". ${ }^{11}$ Each of us, she says, "stands in need of other Beings for ... Support and Happiness". ${ }^{12}$ Her emphasis is on practice and not theory. The aim of

\footnotetext{
9 Masham as quoted by Springborg, Mary Astell, 74.

${ }^{10}$ For this correspondence see Broad, Women Philosophers (2020).

11 Damaris Masham, A Discourse Concerning the Love of God (London, 1695), 123.

12 Ibid., 21.
} 
Christianity is "a good life that ought to be practis'd". ${ }^{13}$ And the practice of this good life entails "the Performance of those Vertues recognised by our saviour Christ". Christian virtue, and indeed human virtue is essentially social, involving "Goodwill Charity, and the being useful to others". Her practical, even worldly ethics (highlighted by the terms practiced, performance, useful) is well-exemplified in her argument for the education of women based on the moral role of women in society. ${ }^{14}$

A deciding factor, which weighs against acknowledging that Damaris's link to Cambridge Platonism, is the empiricist-rationalist divide which has dominated the received picture of the history of early modern philosophy. This sets Locke and the Cambridge Platonists firmly apart, largely on account of their differences in epistemology. As a result, the identifiable Lockean elements in Damaris Masham's philosophy, especially in epistemology, suggest that she should be placed firmly with Locke against the Platonists, with whom her links are merely biographical.

However, the question of Damaris's debt to Platonism cannot be settled so straightforwardly. The first point I would make is that there are many strands within Platonism - ranging from the mystical to the sceptical. Among the varieties of Christian Platonism on offer in the seventeenth-century is the version that has since become known as Cambridge Platonism, of which Damaris Masham's father, Ralph Cudworth, was a leading proponent. Cambridge Platonism itself was not homogenous. The term is a label of convenience, coined in the nineteenth century, for a number of overlapping strands of English Platonising thought. Not all the those identified as Cambridge Platonists subscribed to the same theories: James Buickerood's "litmus test" for Cambridge Platonism (the one tenet which he adduces in evidence) is the conception of immaterial agency which two of them held - Cudworth called it "Plastic Nature", and More, "the Spirit of Nature". However, Damaris's not holding a corresponding doctrine does not disqualify her as a Cambridge Platonist (as Buickerood wants to claim), since others of their number did not

${ }^{13}$ Ibid., 2. My italics. It follows from this that the contemplative life advocated by some Christians (notably Roman Catholics), and held by them to be superior to vita activa, separates religion from morality (i.e. the practice of virtue) and is therefore a "reproach [to] the Wisdom of God".

${ }^{14}$ Hutton, "Damaris Cudworth, Lady Masham". 
hold it (e.g. Benjamin Whichcote). The Platonism of her paternal background was a rationally-grounded Christian Platonism, receptive to the new science and philosophy of the seventeenth century. It is very much not the mystical or rapturous Platonism of the kind which Damaris critiques in her Discourse concerning the Love of God. The "pompous rhapsodies", which Patricia Springborg identifies as Platonism, is better represented by the high-flown enthusiasm of the likes of Norris and Malebranche. By contrast, Cudworth, for all his abstruse scholarship, was very much concerned with how we think and act in the here and now. Springborg and Buickerood's view of Damaris Masham as a "doctrinal minimalist opposed to the fractiousness induced by rival Christian camps", applies every bit as much to Cudworth. Furthermore, contrary to common assumptions, Cudworth's innatist epistemology does accord sense perception a role in cognition - albeit a secondary role. ${ }^{15}$ And recent work on Cudworth's moral philosophy highlights his affinities with moral sentimentalism rather than moral rationalism. ${ }^{16}$ Moreover, it has been plausibly argued that there are Platonist elements in Locke's thought. ${ }^{17}$ As a result, it is beginning to be recognised that there is more common ground between Locke and Cudworth than the empiricist-rationalist divide allows. What I now want to argue is that Damaris Masham's philosophical writings indicate a philosophical position which does not fit these categories. I shall do so by highlighting affinities with Cudworth, which blur the empiricistrationalist line between Cudworth and Locke. In what follows, I shall focus on Damaris Masham's last-published work, Occasional Thoughts, to highlight some of the ways in which her Cudworthian inheritance challenge the view of her as a disciple of Locke.

15 See Introduction to Ralph Cudworth, A Treatise concerning Eternal and Immutable Morality and A Treatise of Freewill, ed. Sarah Hutton (Cambridge: Cambridge University Press, 1996) (herafter cited as EIM).

16 Michael B. Gill, "From Cambridge Platonism to Scottish Sentimentalism", The Journal of Scottish Philosophy, 8 (2010): 13-31.

17 Victor Nuovo, "Reflections on Locke's Platonism" in his Christianity, Antiquity, and Enlightenment: Interpretations of Locke (Dordrecht: Springer, 2011); Broad, "A Woman's Influence?", Matthew A. Leisinger, "The Inner Work of Liberty: Cudworth on Desire and Attention”, International Journal of Philosophical Studies 27, 5 (2019): 649-667. 


\section{Occasional Thoughts}

As its title suggests, Occasional Thoughts is not a work of systematic philosophy: the epistemological and ethical grounds of Lady Masham's philosophy are not stated formally, but have to be inferred from her discussions of practical morality, the relationship of reason to religion and of religion to virtuous conduct. These show that in the course of her discussions she deals with some of the major areas of intellectual philosophical debate in her time, in epistemology, moral philosophy and metaphysics. ${ }^{18}$ There is much in the detail of what she argues that echoes Locke, whose Reasonableness of Christianity and Thoughts concerning Education she cites approvingly. But there are also echoes of Cudworth, and these Cudworthian echoes, furthermore, are of core elements of his philosophical system. As listed in the opening pages of his magnum opus, The True Intellectual System of the Universe, these are the existence of an essentially good and just God, the real existence of moral principles of morality and the moral autonomy of human beings. ${ }^{19}$ Together with Cudworth's epistemological nativism these are integral to the Platonist core of his philosophy.

\section{Reason and Morality}

Occasional Thoughts shows areas of broad agreement between Damaris Masham, Cudworth and Locke on the goal of moral conduct and the role of reason in achieving moral direction. She does not differ from either in holding that moral philosophy is not merely theoretical. The principles

18 As Marcy B. Lascano has pointed out, although Masham writes disparagingly of metaphysics in A Discourse, her writings discuss topics such as the existence and nature of God, which are now considered metaphysical. Marcy B. Lascano, "Heads Cast in Metahysical Moulds'. Damaris Masham on the Method and Nature of Metaphysics", in Early Modern Women on Metaphysics, ed. Emily Thomas (Cambridge: Cambridge University Press, 2018), $1-27$.

19 Ralph Cudworth, The True Intellectual System of the Universe (London, 1678), Sig A34. 
of morality, however abstractly conceived, must translate into action. But virtuous conduct is not just a matter of adhering to prescribed precepts or performing a few good deeds. On the Lockean side, her views are compatible with his formulation that ethics is "the seeking out of those Rules and Measures of humane Actions, which lead to Happiness, and the means to practise them" (Essay 4.21.3). Like Locke, she emphasises the importance of habit for inculcating virtuous behaviour. She acknowledges the importance of pleasure, including sensual pleasure, in directing us towards happiness. However, she does not adopt Locke's pleasure/pain index of good and evil (Essay 2.28.5). ${ }^{20}$ And she argues that although we are motivated to act by desire of happiness, it is reason that enables us to identify the greater good instead of merely following pleasurable sensations. Reason is important for providing us with knowledge of God's will, and thereby for helping us to discern our duties. Revelation teaches men about the ultimate sanctions, the rewards and punishments of the afterlife. Such sanctions enforce obedience to the law of rectitude, but they are not the foundation of morality. As Cudworth would have agreed, true morality (the measure of human actions) is founded in the "Reason and Truth of Things". It does not vary from country to country, or between religions or according to custom. "The law of Reason, or Nature", comprises, "Those dictates which are the result of the determinate and unchangeable constitution of things", and it is "discoverable to us by our rational Faculties". 21

At the same time Lady Masham, like Locke, underlines the fallibility of human reason. She cites the authority of his Reasonableness of Christianity as "the only Book wherein they have found the insufficiency of Natural Light to Natural Religion, has been fully shewed".22 Had Locke and Lady Masham so wished, they could have cited Cudworth's True Intellectual System where the shortcomings of human reason are well-illustrated in the false and atheistic philosophies he examines. If, for Lady Masham, unassisted natural reason has led to errors in belief and moral conduct, this is not the case for reason

${ }^{20}$ Good and evil are "nothing but Pleasure and Pain, or that which occasions, or procures Pleasure or Pain to us".

${ }^{21}$ Ibid., 54.

22 Damaris Masham, Occasional Thoughts in Reference to a Vertuous or Christian Life (London, 1705) (hereafter OT), 109. 
assisted by revelation. Reason aligned with Christian truth is what she terms "right reason" ("the prescriptions of right Reason, or of the Gospel ... are but one, and the same, differently promulg'"). Reason in this sense is key for directing us to the good. Those who are guided by "the Reason and Truth of Things" as well as revelation adhere to the Law of right Reason, which is "founded in Relations and Connexions, which are as immutable as that determinate constitution in Things, which makes everything what it is". ${ }^{23}$ That reason requires enhancement in order to grasp the divine truth is a view she had defended against Locke in their early correspondence when discussing the ideas of the Cambridge Platonist, John Smith. ${ }^{24}$ Although Damaris Masham does not use the term "right reason" in that discussion, her endorsement of right reason in Occasional Thoughts indicates that she adhered to the principle that reason might be enhanced by religious truth.

\section{Knowledge and God}

As far as her epistemology goes, the impact of Locke on Damaris Masham is well-attested. This may be illustrated from the following statement, in which she gives an account of the state of nature in what is probably a side-swipe at Hobbes. In a state of nature, men have

no extrinsick law to direct them, but indu'd only with a faculty of comparing their distant Ideas by intermediate Ones, and thence of deducing, or inferring one thing from another; whereby our Knowledge immediately received from Sense, or Reflection is in enlarg'd to a view of Truths remote, or future, in an Application of which Faculty of the mind to a consideration of our own Existence and Nature, together with the beauty of the Universe ... we may come to the knowledge of a first Cause; and that this must be an Intelligent Being, Wise and Powerful, beyond what we are able to conceive. ${ }^{25}$

23 Ibid., 98.

24 Locke, Correspondence, vol. 2, letters 684, 687.

25 OT, 61. "extrinsick" is misprinted in the text as "intrinsick", but it is corrected to "extrinsick" in the errata. 
The echoes of Locke are obvious enough in reference to ideas of sense and reflection, and the description of cognition as a process of comparing ideas. The passage is certainly true to Lockean epistemological principles in acknowledging the importance of ideas derived from the senses. Also, it is arguably perfectly in accordance with Locke that an important role be accorded to the mind, or "faculty of comparing ... distant ideas by intermediate ones". The passage could almost be a summary of Essay 4.10, proceeding as it does from knowledge of oneself (4.10.2), through to God's wisdom (that he is "most knowing") and God's power (4.10.6), extending to the rather attenuated statement of the cosmological argument (God's attributes visible "in the Works of Creation"). However, unlike Locke, Damaris Masham introduces a clear design element ("the beauty of the universe"). And where Locke infers the existence of "an eternal, most powerful and most knowing Being", ${ }^{26}$ Lady Masham makes no mention of God's eternity. This may appear to be a small detail, but it is consistent with comments she made in a letter she wrote to Locke seven years earlier, written in 1688 in response to the epitome of his Essay known as the Abregé, which he had sent her. In the letter, she allows that Locke's argument for the existence of God "is sufficient", but with the reservation that the eternal duration "is not properly but onley Applicatively Successive", disagreeing with Locke that "the Idea of Eternitie shold be form'd from time repeated"). ${ }^{27}$ in Occasional Thoughts she not only refrains from deducing God's eternity, but she goes on to infer the goodness of God:

we cannot from thence but infer, that this Wise and Powerful Being is also most Good, and since he has made us out of nothing to give us a Being wherein we find such Happiness, as makes us very unwilling to part therewith. And thus by consideration of the Attributes of God, vis. In the Works of Creation, we come to a knowledge of his Existence, who is an Invisible Being. ${ }^{28}$

Of course, the idea that knowledge of God is writ large in the book of nature ("the works of creation") is a standard argument in natural theology

26 Essay, 621.

27 Locke, Correspondence, 3: 434. My thanks to Robert Sleigh for drawing my attention to this. As Locke's editor, De Beer, points out, the argument which she uses echoes Cudworth's argument in True Intellectual System, 643-645.

28 OT, 61-62. 
common to both Locke and Cudworth. It is also true that Locke refers to the goodness of God in his writings. But Lady Masham's focusing of her demonstration of the existence of God on divine goodness recalls Cudworth rather than Locke, especially since, a few pages later, she emphasises divine perfection, harmony and benevolence. "The Creator of All Things", she writes,

is an invisible Being only knowable to us in, and by the exemplifications of his Attributes: The infinite Perfection, and the inseparable Harmony of which (discernable in the Frame and Government of the Universe) plainly tell us That the Divine Will ... [is] one steady, uniform, unchangeable result of infinite Wisdom and Benevolence, extending to, and including All his Works. So that Sin, or disobedience to our Maker is manifestly the greatest Non sense, Folly and contradiction conceivable, with regard to the immutable perfection of the Divine Nature; and to the natural constitution of things, independently upon any positive command of God to us, or his irresistable power over us. ${ }^{29}$

In Essay IV.10, Locke refrains from discussing the proof of the existence of God from the "the Idea of a Perfect Being", commenting negatively that to emphasise it is "an ill way of establishing this Truth and silencing Atheists". ${ }^{30}$ For Ralph Cudworth, on the other hand, God is above all else a perfect being - a conception of God which registers his debt to Descartes' ontological argument. For both Cudworth and his daughter God's perfection is reflected in the perfection and order of the world. Furthermore, her emphasis on divine perfection in Occasional Thoughts indicates that she had not abandoned the position which she took in the forementioned 1688 letter to Locke when she told Locke, "I do Think the Demonstration of a God from His Idea Conclusive" - though, as already mentioned, she conceded that, "were there no Other but yours", that would be "sufficient". ${ }^{11}$ Furthermore, as the rest of the passage just quoted shows, she is committed to the non-voluntarist view that Divine Will is subordinate to God's wisdom and goodness: divine will is the

29 Ibid., 69. "Invisible" is an adjective used by Locke when discussing the idea of God (Essay I.3.10), but which Cudworth only employs when discussing pagan theism. Here Lady Masham probably follows Locke in refering to God as an "invisible being".

${ }^{30}$ Locke, Essay, 621-622.

31 See Henry More's formulation of the argument, Antidote against Atheism in his Collection of Several Philosophical Writings (London, 1662), 22. 
"result of infinite Wisdom and Benevolence" (my italics) - a position which is fundamental in Ralph Cudworth. The passage implies, furthermore, that moral principles are absolutes antecedent to the divine command. Sin is not sin because God decrees it to be so, but because it is against nature and contradicts divine perfection. This, too, is a fundamental tenet of Cudworth's moral philosophy. Moreover, Lady Masham's description of sin as "non sense" implies that virtue and godliness are the opposite of irrational. Disobedience to God is an act of "disingenuity" towards our "Sovereign Benefactor" and an act of "folly" in respect of our dependence on him. It is therefore "repugnant to right Reason". In Cudworth's analysis, divine wisdom and goodness are guarantors of truth. False systems of philosophy derive from atheism or from mistaken ideas of the deity.

Lady Masham's emphasis on divine goodness among the attributes of God is a significant indicator of an anti-voluntarist conception of God, which accords with Ralph Cudworth. Where Locke stresses God's power and will, Lady Masham stresses God's wisdom and goodness: God is an "Infinite, Wise and Good Being, which Reason teaches the first cause of things".32 When she mentions God's power, she links it with His Wisdom and Goodness "this Wise and Powerful Being is also most Good". ${ }^{33}$ While she follows Locke in saying that we should obey God's will, and that "manifestations of his Will" should be regarded as his "Commands", she subsumes will within the rational: "the dictates of Reason, or Nature, discernible by our natural Faculties, are the commands of God to us, as rational Creatures". ${ }^{34}$ We obey God, not out of fear of His power, but through free recognition of His goodness.

And as we delight in our selves, and receive pleasure from the objects which surround us, sufficient to indear to us the possession and injoyment of Life, we cannot from thence but infer, that this Wise and Powerful Being is also most Good....

\footnotetext{
32 OT, 55.

33 Ibid., 62.

34 Ibid., 71.

35 Ibid., 61-62.
} 
Lady Masham's anti-voluntarism is perhaps most apparent when she attacks deism, superstition and those theists who conceive of the deity as above all omnipotent and omniscient. Over-emphasis on God's power and omniscience, results in mindless obedience out of fear of God's vengeance. Her emphasis on divine wisdom and goodness over the divine will sets her alongside her father, against the theological voluntarism which he so vehemently opposed. Locke's philosophical voluntarism sets him apart from both.

\section{Relations}

In her explanation of how we arrive at knowledge of God Lady Masham also applies a theory of relations. We are, she says, able to distinguish the "difference in Things; as between Power and Weakness, Benevolence and no Benevolence or its contrary" etc. ${ }^{36}$ And "every intelligent Agent, so far as he $(s i c)$ is made capable of discerning these relations, dependencies and consequences" is able to arrive at a knowledge of God's will by considering them. ${ }^{37}$ Coupled with the terms "dependencies and consequences" relations appear to include cause, effect and power. These are all types of relations discussed by Locke in the Essay, but they also figure in Cudworth's epistemology and ethics.

It is a central plank of Cudworth's epistemology, as outlined in his Treatise Concerning Eternal and Immutable Morality that "Wisdom, knowledge and ... are eternal and self-subsistent things", so much so that they are not only the same in all times and places, but are capable of existence even in the absence thinking minds and of the universe,

Nay, though all the material world were quite swept away, and also all particular created minds annihilated together with it, yet there is no doubt but the intelligible natures or essences of all geometrical figures, and the necessary verities belonging to them, would notwithstanding remain safe and sound. Wherefore

36 Ibid., 63.

37 Ibid. 
these things had a being also before the material world and all particular intellects were created. ${ }^{38}$

Cudworth refers variously to eternal verities, "universal rationes", intelligible natures and essences of all things. Since these, he argues, are not derived via the senses, they must be generated by the activity of the mind: they include "the ideas of wisdom, folly, prudence, imprudence, knowledge, ignorance, verity, falsity, virtue, vice, honesty, dishonesty, justice, injustice, volition, cogitation, nay of sense itself". ${ }^{39}$

Cudworth, like Locke, also distinguishes a category of mind-generated ideas that he calls relations which are an important component of cognition. These relative ideas, which he also calls scheses, include "logical notions" such as "cause, effect, means, end, order, proposition similitude, dissimilitude, equality, inequality, aptitude, inaptitude, symmetry, asymmetry, whose and part, genus and species, and the like". ${ }^{40}$ These ideas are the "prolepses" or "intellectual anticipations" whereby the mind is able to comprehend the world. External nature bears corresponding "passive stamps and impresses", from which the mind can deduce the existence of God and of morality, "For the man hath certain moral anticipations and signatures stamped inwardly upon his soul, which make him presently take notice of whatsoever symbolizes with it in corporeal things". ${ }^{41}$ Indeed, Cudworth also goes so far as to state that the same proportionality in nature which makes music harmonious to the human listener, is not just a "stamp of intellectuality" but a "signature of morality"

Nay, further, the man will also espy some symbolical resemblances of morality, of virtue and vice in the variously proportioned sounds and airs. For there are ethical ... as well as enthusiastical harmonies ... as the physiognomists in like manner observe in the countenances of men and their pictures. ${ }^{42}$

\footnotetext{
38 EIM, 127.

39 Ibid., 83.

40 Ibid., 84.

${ }^{41}$ Ibid., 98.

42 Ibid.
} 
Lady Masham makes no such statement of epistemological and moral realism. Nonetheless, as already observed, she too employs the concept of relations. These are what the mind discerns when it compares the ideas presented to it. They are founded on difference. We are, she says "indu'd ... with a capacity of perceiving and distinguishing these differences of things" ${ }^{43}$ And these differences or "relations", are constants of some kind, and multiplicitous: "From which diversity and immutability in the Nature of things, there necessarily arises a diversity of respects and relations between them, as unchangeable as the things themselves" ${ }^{44}$ Notably, when she discusses the process of cognition, Lady Masham does not discuss ideas of sensation and reflection, aside from mentioning them twice. She does, however, use the term "relation" on a number of occasions. Likewise, the "Law of right Reason" is not arbitrary but is "founded in Relations, and Connexions, which are as immutable as that determinate constitution in Things, which makes every thing what it is". ${ }^{45}$

For Lady Masham "relations" are eternal and immutable, and she includes moral principles in the same category of intelligible ideas. The principles of morality are, she says, evident in the nature of things as "that unalterable Rule of Rectitude, discoverable to us by the Nature of Things" ${ }^{46}$ There is, she writes, "an inseparable connection or relation of Moral Good and Evil, with our Natural Good, and Evil", ${ }^{47}$ while Virtue and vice," have the same reality, in Nature as their [men's] Happiness and Misery have". ${ }^{48}$ She echoes Cudworth, every bit as much as Locke, when she observes that it is easy to dismiss moral principles as merely hypothetical. But she is closer to Cudworth, in holding that they are actually part of the order of things, antecedent to any divine commands:

Moral Good, and Evil, considered antecedently to any positive Law or our Maker, are apt to be thought but a Notion where that inseparable Relation

\footnotetext{
43 OT, 65.

44 Ibid., 63.

45 Ibid., 98.

46 Ibid., 72.

7 Ibid., 78.

${ }^{48}$ Ibid., 81.
} 
is overlook'd which there is between actions denominated by us virtuous, or vicious, and the Natural Good, and Evil of Mankind. ${ }^{49}$

Relations are perceptible by reason and constitute the dictates of God, in so far as we are rational creatures.

\section{Free Will}

Another key tenet of Ralph Cudworth's philosophy which Lady Masham shared is that freedom of action or free will is essential for the exercise of virtue. Human beings, she argues, are not just rational creatures, "with a capacity of perceiving and distinguishing these differences of Things", but they are endowed "with a liberty of acting, or not, suitably and agreeably hereunto". Virtuous conduct is not just is founded in reason but requires the freedom to act, "its extent is equal to our liberty of action; and its Principle the most Active one of the Mind". ${ }^{0}$ There are echoes of both Cudworth and Locke, in her definition free will in terms of agency as "Liberty of Action" and in her account of its exercise as determination. Freedom of action is a human attribute which distinguishes men from God, whose will "cannot be (like ours) Determinations without dependance, or connection one upon another; much less inconsistent, contradictory and mutable". She echoes Cudworth in particular when she ties freedom of action to moral responsibility and links it to human imperfection. As free agents, human beings are at liberty to obey God or not, as they choose. "No agent", she writes, "can offend farther than he wilfully abuses the Freedom he has to act". ${ }^{11}$ Freedom to act is freedom to disobey, that is the result of "creaturely imperfection".52 But, as with Cudworth, for Damaris Masham liberty of action brings with it the possibility of increasing perfection. Without it, there would be "no desert, or self-excellency in any

\footnotetext{
49 Ibid.

${ }^{50}$ Ibid., 11.

51 Ibid., 71

52 Ibid., 69.
} 
Created Being". ${ }^{33}$ As with her father, this is directly connected to her antivoluntarism.

\section{Defence of Ralph Cudworth}

A difficulty to be faced when arguing for Cudworth's importance for his daughter's philosophy, is that Cudworth's writings on moral philosophy were unpublished when he died, ${ }^{54}$ and there is some question as to whether Damaris Masham had access to his manuscripts. ${ }^{55}$ However, The True Intellectual System of the Universe (1678) broaches many of the ethical and epistemological issues discussed in the manuscripts, including most of the Cudworthian echoes identified above. And, it is possible that the manuscript of $A$ Treatise Concerning Eternal and Immutable Morality was owned by the Mashams, since it was her son, Francis Cudworth Masham, who made it available for printing in 1731.

Be this as it may, Damaris Masham evidently had a good knowledge of her father's book. For evidence that she was conversant with her father's philosophy, it is instructive to examine her own comments on it, recorded in a letter to Leibniz. This letter was written in 1705, the year in which Occasional Thoughts was published. It was written after the death of Locke against the background of controversy stirred up by Pierre Bayle's critique of Cudworth's hypothesis of Plastic Nature. ${ }^{56}$ In the letter, Lady Masham urges Leibniz to

53 Ibid., 69.

${ }^{54}$ Cudworth's ethical writings were unpublished when he died. From among these, A Treatise Concerning Eternal and Immutable Morality was published in 1731, and A Treatise of Freewill in 1838. The British Library holds the unpublished remainder. See my Introduction to the modern edition of both texts (CUP 1996).

${ }_{55}$ Broad, "A Woman's Influence?".

56 Originally published in Basnage de Beauval's Histoire des Ouvrages des Savants, Bayle's critique was printed in his own Continuation des pensées diverses sur la comète, and republished in his Euvres Diverses (The Hague: P. Husson et al., 1727). The dispute is discussed by Luisa Simonutti, "Bayle and Leclerc as Readers of Cudworth. Elements of the Debates on Plastic Nature in Dutch Learned Journals", Geschiedenis van de Wijsbegeerte in Nederland 40 (1993): 147-165; Susan Rosa, "Ralph Cudworth in the République des Lettres: The Controversy about 
defend his philosophy (to set it "in a just light"), mindful of the fact that she is largely dependent for her knowledge of it on Bayle's account of it, and mindful also that Bayle could distort the arguments of which he gives accounts. Of this, she has direct experience in the case of his account of one of the key hypotheses of Cudworth's, his hypothesis of Plastic Nature (or Natures) set out in his True Intellectual System of the Universe. ${ }^{57}$ Although Cudworth does not conceive Plastic Nature as a deity, Bayle attacked his hypothesis as conducive to atheism, arguing that, as an agent which acts independently of God, it destroys the need for a deity. Far from illustrating the workings of Providence (as Cudworth claims), Plastic Nature undermines the very idea of providence since it operates unknowingly, literally "unconscious" of what it does.

In her letter to Leibniz, Lady Masham defends her father. She denies that on his account, nature is blindly autonomous. Nature is not endowed with knowledge, but acts as God's instrument, that is, as the agent of divine providence.

my Father does not therein assert (as Mr. Bayle says he dos) that God has been able to give to Creatures a faculty of produceing excellent works (viz. such as is the organisation of plants and animals) separate from all knowledge etc.: but onlie a facultie of executeing instrumentally his Ideas or Designs in the production of such excellent works. ${ }^{58}$

Plastick Nature and the Reputation of Pierre Bayle", Studies in Eighteenth-Century Culture 23 (1994): 157-160.

${ }^{57}$ Cudworth, True Intellectual System, 147-176. Plastic Nature is the equivalent, in Cudworth's philosophy, of the Spirit of Nature or Hylarchic Principle in Henry More's philosophy. Cudworth conceives it as an instrument of the deity, the executor which is charged with the day-to-day running of the cosmos. See my entry on Ralph Cudworth in the Stanford Encyclopedia of Philosophy.

${ }_{58}$ Masham to Leibniz, 20 October 1705, in Die Philosophischen Schriften von Gottfried Wilhelm Leibniz, vol. III, ed. C. I. Gerhardt (Berlin: Georg Olms Hildesheim, 1960), 370-371. On the Masham Leibniz correspondence, see Sarah Hutton, "Religion and Women's Letters: Anne Conway and Damaris Masham", in Debating the Faith Religion and Letter-Writing in Great Britain, 1550-1800, eds. Anne Dunan-Page, Clotilde Prunier (Dordrecht: Springer, 2013); Pauline Phemister, “All the Time and Everywhere Everything's the Same as Here': The Principle of Uniformity in the Correspondence Between Leibniz and Lady Masham", in Leibniz and His Correspondents, ed. Paul Lodge (Cambridge: Cambridge University Press, 2004); Robert Sleigh, "Reflections on the Masham-Leibniz Correspondence", in Early Modern 
In correcting Bayle's account of Cudworth, Lady Masham restates the fundamental Cudworthian premise that mind precedes matter, intellect precedes the world.

to the production of such a work [of nature] as this two things according to my father) must concur viz. the idea of the work to be executed, with an executive power of bringing this idea into real existence: and it is only the last of these which he ascribes to plastic natures..$^{59}$

This position is premised on an ontology where Divine Wisdom (divine ideas and divine knowledge) is primary. Nature cannot generate anything, "the ideas whereof were never in any understanding". The creation of the natural world and the production or generation of things in nature are inseparable from ideas -

there is ... an inseparable union betwixt the power of producing excellent works, and the idea of their essence and manner of produceing them. ${ }^{60}$

The power to generate or reproduce is subordinate to ideas and the divine intellect. Lady Masham declares,

the operations of the plastick nature to be essentially and necessarilie dependent on the ideas in the divine intellect. ${ }^{61}$

Lady Masham's defence of her father does not mean that she agreed with him on all points. But it does show that she was thoroughly acquainted with his intellectualist view of God and his Platonist ontology. She was, moreover, astute enough to recognise, as Bayle did not, that Cudworth's hypothesis was framed in a different Cartesian context from the one that obtained when Bayle was writing. She probably had Malebranche in mind when she

Philosophy. Mind, Matter and Metaphysics, eds. Christia Mercer, Eileen O’Neill (Oxford: Oxford University Press, 2005).

59 Die Philosophischen Schriften, vol. III, 371.

60 Ibid., 370-371.

61 Ibid., 371. 
mentions occasionalism as one of the differences between "modern Cartesians" and "their master":

Mr Bayle is mistaken ... in presuming that my father designed in introducing his Hypothesis to oppose the modern Cartesians: whereas he (no understanding French) did not know that the modern Cartesians differed so much from their master as to hold that God was the immediate efficient cause of all effects of nature. And the hypothesis of plastic nature ... was very far from having the Cartesians in view. ${ }^{62}$

Lady Masham's observations on the Bayle-Cudworth controversy are not the views of a dependent mind. Rather, they are astute and challenging, and framed specifically to address the case at issue - posthumous criticisms of Cudworth, for which there was no ready-made Cudworthian response for his daughter to rehearse. ${ }^{63}$

\section{Conclusion}

In many respects, the common ground between Damaris Masham and her father is the ground that Locke also shares. So the least result of this limited exercise of comparison is to throw into focus how much Locke and Cudworth have in common. More important is what the echoes of both reveal about her own philosophical position. Her differences from Locke suggest that even while being receptive to Locke's philosophy, she remained committed to views she had formed before she read his Essay. The divide separating Locke from the Cambridge Platonists on most of the points discussed was not so large that Damaris Cudworth was inconsistent in accepting Locke's philosophy in many particulars, while at the same time adhering to views associated with her father. However, there is more work to be done on this. The affinities with Cudworth in Occasional Thoughts mean it is implausible to

\footnotetext{
62 Ibid.

${ }^{63}$ Hutton, "Religion and Women's Letters".
} 
interpret her as repudiating earlier Platonist views. ${ }^{64}$ It is therefore no longer possible to explain the differences between her letters and her published writings as displaying a straightforward shift from a Platonist to a Lockean position. ${ }^{65}$ Furthermore, receptivity is not a one-way street. A question that has yet to be fully explored is the extent to which she may have influenced Locke's later writings. ${ }^{66}$ Of particular relevance to my discussion here are the two works she cites in Occasional Thoughts: The Reasonableness of Christianity and Some Thoughts concerning Education. On the evidence I have presented from Occasional Thoughts, her last published work, she was not a Platonist in a strong sense of the term, but she was not so far from being a "Cambridge Platonist" like her father. It is therefore particularly unhelpful to rely on the preset categories of empiricist and rationalist to classify her as a philosopher. Understanding where she sits in relation to other philosophers requires us to rethink how they have traditionally been perceived. The example of Damaris Masham illustrates that restoring women to the history of philosophy is not a matter of filling gaps in the narrative but revising the narrative itself.

\section{References}

Broad Jacqueline. 2020. Women Philosophers of Seventeenth-Century England: Selected Correspondence. Oxford: Oxford University Press.

Cudworth Ralph. 1678. The True Intellectual System of the Universe. London.

Cudworth Ralph. 1996. A Treatise concerning Eternal and Immutable Morality and A Treatise of Freewill, ed. Sarah Hutton. Cambridge: Cambridge University Press.

Die Philosophischen Schriften von Gottfried Wilhelm Leibniz. 1960. vol. III, ed. C. I. Gerhardt. Berlin: Georg Olms Hildesheim.

Locke John. 1976-1989. The Correspondence of John Locke, 8 Volumes, ed. E. S. de Beer. Oxford: Clarendon Press.

${ }^{64}$ As, e.g. Susan Whyman, in an otherwise insightful article: Susan Whyman, "The Correspondence of Esther Masham and John Locke: a study in epistolary silences", Huntington Library Quarterly 66, 3, 4 (2004): 275-305.

65 This was my conclusion in "Damaris Cudworth, Lady Masham".

${ }^{66}$ Jacqueline Broad discusses the possibility that it was Damaris who influenced Locke's revisions to his Essay. Broad, "A Woman's Influence". 
Locke John. 1975. An Essay concerning Human Understanding, ed. Peter H. Nidditch. Oxford: Clarendon Press.

Masham Damaris. 1695. A Discourse Concerning the Love of God. London.

Masham Damaris. 1705. Occasional Thoughts in Reference to a Vertuous or Christian Life. London.

More Henry. 1662. A Collection of Several Philosophical Writings. London.

\section{Studies}

Acworth Richard. 2006. "Cursory reflections upon an article called 'What is it with Damaris, Lady Masham?"'. Locke Studies 5: 179-197.

Broad Jacqueline. 2002. Women Philosophers of the Seventeenth Century. Cambridge: Cambridge University Press.

Broad Jacqueline. 2003. "Adversaries or Allies? Occasional Thoughts on the Masham-Astell Exchange". Eighteenth-Century Thought 1: 123-149.

Broad Jaqueline. 2006. "A Woman's Influence? John Locke and Damaris Masham on Moral Accountability". Journal of the History of Ideas: 489-490.

Buickerood James G. 2005. "What is it with Damaris, Lady Masham? The Historiography of one early modern woman philosopher". Locke Studies. An Annual Journal of Locke Research 5: 179-214.

Gill Michael B. 2010. "From Cambridge Platonism to Scottish Sentimentalism", The Journal of Scottish Philosophy, 8: 13-31.

Goldie Mark. 2007. "Mary Astell and John Locke". In Mary Astell: Reason, Gender, Faith, eds. William Kolbrener, Michal Michelson. New York: Routledge.

Hammou Philippe. 2008. "Enthousiasme et Nature Humaine: à propos d'une Lettre de Locke à Damaris Cudworth". Revue de Métaphysique et Morale 3: 337-350.

Hutton Sarah. 1993. "Damaris Cudworth, Lady Masham: Between Platonism and Enlightenment". British Journal for the History of Philosophy 1, 1:29-54.

Hutton Sarah. 2013. "Religion and Women's Letters: Anne Conway and Damaris Masham". In Debating the Faith Religion and Letter-Writing in Great Britain, 1550-1800, eds. Anne Dunan-Page, Clotilde Prunier. Dordrecht: Springer.

Hutton Sarah. 2015. "Blue-eyed Philosophers Born on Wednesdays': An Essay on Women and History of Philosophy". The Monist 98, 1.

Hutton Sarah. 2020. "Lady Damaris Masham". The Stanford Encyclopedia of Philosophy (Winter 2020 Edition), ed. Edward N. Zalta, https://plato.stanford.edu/ archives/win2020/entries/lady-masham/.

Hutton Sarah, 2021, "Ralph Cudworth", The Stanford Encyclopedia of Philosophy (Summer 2021 Edition), Edward N. Zalta (ed.), URL $=<$ https://plato.stanford. edu/archives/sum2021/entries/cudworth/> 
Lascano Marcy B. 2011. "Damaris Masham and 'The Law of Reason or Nature". The Modern Schoolman 88, 3-4: 245-265.

Lascano Marcy B. 2018. “'Heads Cast in Metahysical Moulds'. Damaris Masham on the Method and Nature of Metaphysics", 1-27. In Early Modern Women on Metaphysics, ed. Emily Thomas. Cambridge: Cambridge University Press.

Leisinger Matthew A. 2019. "The Inner Work of Liberty: Cudworth on Desire and Attention". International Journal of Philosophical Studies 27, 5: 649-667.

Nuovo Victor. 2011. Christianity, Antiquity, and Enlightenment: Interpretations of Locke. Dordrecht: Springer.

Phemister Pauline. 2004. "All the Time and Everywhere Everything's the Same as Here': The Principle of Uniformity in the Correspondence Between Leibniz and Lady Masham". In Leibniz and His Correspondents, ed. Paul Lodge. Cambridge: Cambridge University Press.

Rosa Susan. 1994. "Ralph Cudworth in the République des Lettres: The Controversy about Plastick Nature and the Reputation of Pierre Bayle". Studies in EighteenthCentury Culture 23: 157-160.

Shapiro Lisa. 2004. "The Place of Women in Early Modern Philosophy”. In Feminist Reflections on the History of Philosophy, ed. Lilli Alanen, Charlotte Witt. Dordrecht: Kluwer.

Simonutti Luisa. 1993. "Bayle and Leclerc as Readers of Cudworth. Elements of the Debates on Plastic Nature in Dutch Learned Journals". Geschiedenis van de Wijsbegeerte in Nederland 40: 147-165.

Sleigh Robert. 2005. "Reflections on the Masham-Leibniz Correspondence". In Early Modern Philosophy. Mind, Matter and Metaphysics, ed. Christia Mercer, Eileen O'Neill, 119-126. Oxford: Oxford University Press.

Springborg Patricia. 2005. Mary Astell: Theorist of Freedom from Domination. Cambridge: Cambridge University Press.

Whyman Susan. 2004. "The Correspondence of Esther Masham and John Locke: a study in epistolary silences". Huntington Library Quarterly 66, 3, 4: 275-305. 